\title{
HR MARKETING - ATTRIBUTES OF EMPLOYEE RETENTION
}

\author{
[Personální marketing - atributy stabilizace zaměstnanců] \\ Kateřina Maršíková ${ }^{1}$, Světlana Myslivcová ${ }^{2}$ \\ ${ }^{1}$ Technická univerzita v Liberci, Ekonomická fakulta, Studentská 1402/2, 46117 Liberec \\ Email:katerina.marsikoval@tul.cz. \\ ${ }^{2}$ Technická univerzita v Liberci, Ekonomická fakulta, Studentská 1402/2, 46117 Liberec \\ Email:svetlana.myslivcova@tul.cz.
}

\begin{abstract}
This paper deals with the topic of HR marketing and factors of the employee retention implicated on the primary data of large and medium enterprises in the Liberec region. In the theoretical part the aim of the paper is to introduce a concept of the HR marketing and aspects of employer branding as an important factor for employee retention. The empirical part aims to evaluate an extent of usingusing of internal HR marketing tools and their importance for an employee retention. Attributes of the employee retention as an important part of the employer branding are evaluated by specialists from large and medium enterprises in the Liberec region. The importance of these attributes is statistically tested and results prove crucial factors to support quality of employer branding and thus to keep the best and motivated employees. The paper confirms that tools of HR marketing play an important role in the employee and potential employee satisfaction.
\end{abstract}

Keywords: communication, employer branding, employees stabilisation, HR marketing.

JEL classification: M31, M51

Doručeno redakci: 26.11.2015; Recenzováno: 6.12.2015; 9.12.2015; Schváleno k publikování: 24.8.2016

\section{Úvod}

Konkurenceschopnost a úspěšnost firmy v současné době nesouvisí pouze s nabízeným produktem, který uspokojuje potřeby zákazníka, ale také $\mathrm{s}$ tím, jak firma vystupuje $\mathrm{v}$ roli zaměstnavatele. Jak uvádějí autoři Wahba a Elmanadily (2015), Dew-Becker a Gordon (2012) či Gaddam (2008), současné podnikatelské prostředí a s ním i trh práce se mění ve vysokém tempu. Kvalitní a kvalifikovaná pracovní síla (označovaná jako lidský kapitál) představuje významnou formu nehmotných aktiv, kterými firma disponuje a které může zhodnocovat. Jsou to právě kvalifikovaní a perspektivní zaměstnanci, kteří mohou firmě pomoci zvládnout ekonomicky neúspěšné období a dopomoci ji k hospodářskému růstu. Vhledem k současné situaci na trhu práce, kdy je pro firmy stále obtížnější najít kvalitní zaměstnance, nabývá využívání nástrojů personálního marketingu a budování kvalitní značky zaměstnavatele na stále větším významu. Firmy si také kvalitní zaměstnance musí udržet a nástroje personálního marketingu, které podporují budování kvalitní značky zaměstnavatele, jsou pro stabilizaci zaměstnanců $\mathrm{v}$ dnešní době klíčové.

Cílem př́spěvku je zhodnotit míru využívání personálního marketingu (HR marketingu) a konkrétně hlavních nástrojů využívaných v oblasti interního personálního marketingu, které př́mo korespondují s kvalitní značkou zaměstnavatele (s tzv. employer brandingem). Úvodní část př́íspěvku je věnována teoretickým východiskům personálního marketingu a budování employer brandingu, která byla získána prostřednictvím rešerše odborné vědecké literatury. V empirické části jsou prezentovány dílčí výsledky dotazníkového šetření, zaměřeného na zhodnocení využívání nástrojů interního personálního marketingu, které podporují udržení (stabilizaci) a spokojenost kvalitních zaměstnanců. Pomocí vybraných statistických metod je hodnocena důležitost nástrojů pro stabilizaci zaměstnanců a budování značky zaměstnavatele. 
Primární data jsou porovnána v závislosti na velikosti podniku (velké a střední) u firem, které jsou největšími zaměstnavateli Libereckého kraje. Na základě výsledků jsou identifikovány hlavní atributy, které z pohledu těchto společností hrají klíčovou roli pro udržení si klíčových zaměstnanců a tím i budování kvalitní značky zaměstnavatele.

\section{Teoretická východiska personálního marketingu}

V souvislosti s personálním marketingem přináší literatura několik pojmů, které jsou vymezeny $\mathrm{v}$ následujícím textu. Významnou součástí personálního marketingu je oblast značky zaměstnavatele.

\subsection{Personální marketing}

Jak uvádí ve svém díle Dvořáková (2004), pojem personální marketing (označovaný v literatuře také jako HR marketing) se objevil poprvé v německé personální práci. Dle Meiera (1991) byl tento pojem již v šedesátých letech spojován se získáváním pracovní síly, konkrétně s nedostatkem vysokoškolsky vzdělané pracovní síly. V souvislosti s nedostatkem poptávané pracovní síly si ve zmiňovaném období manažeři firem začali uvědomovat důležitost kvalifikované pracovní síly a konkurenční výhodu z ní plynoucí. Důsledkem bylo, že se personální marketing vyčlenil z oblasti řízení lidských zdrojů. Na personální marketing začalo být nahlíženo $\mathrm{z}$ tradičního marketingového pohledu. Ten vycházel $\mathrm{z}$ nástrojů marketingového mixu (4P: product, place, price, promotion), kde bylo pracovní místo definováno jako produkt a na zaměstnance bylo nahlíženo jako na zákazníka, kterému je pracovní místo nabízeno. Cílem personálního marketingu bylo vytvořit komplexní systém získávání a udržení zaměstnanců a snížení fluktuace. Postupně se personální marketing rozvíjel i v praxi, a jak uvádí Fazard (2008), zaměstnanec začal být vnímán jako partner společnosti.

V současnosti je dle Wimmerse (2009) cílem personálního marketingu především budování pozitivního vlivu na všechny, kteří se o organizaci zajímají nebo by se o ni mohli zajímat. Jde o budování atraktivity organizace pro ambiciózní a motivované budoucí zaměstnance, kteří jsou klíčem k udržitelnosti organizace. $Z$ definice je patrné, že dochází ke spojování pojmů personální marketing a budování značky zaměstnavatele (employer branding), a že se hlavním nástrojem personálního marketingu stává komunikace. Ungerman (2015) ve svém odborném článku v souvislosti s komunikací uvádí, že jedním z důležitých prostředků personálního marketingu jsou sociální média. Zaměstnavatelé cílí své aktivity na budování jména dobrého a atraktivního zaměstnavatele, který je veškerou veřejností vnímám pozitivně. Se svými stávajícími zaměstnanci budují tito zaměstnavatelé dobré, kvalitní a dlouhodobé vztahy, potenciálními uchazeči o pracovní místo jsou cíleně vyhledáváni.

Autoři Walter a Förster (2015) ve svém díle poukazují na to, jak důležití jsou pro firmu její zaměstnanci, stávající i budoucí, a také na to, že se stále více personálních pracovníků a HR manažerů uchyluje k využívání personálního marketingu, a to jak externího, tak interního. Externí personální marketing lze dle Dvořákové (2004) chápat jako dlouhodobé získávání lidských zdrojů z externího trhu práce a vytváření pozitivního image zaměstnavatele na trhu práce, interní personální marketing lze dle autorky chápat jako opatření zaměřená ke zvýšení stabilizace stávajících zaměstnanců.

\subsection{Značka zaměstnavatele a její význam pro udržení kvalitních zaměstnanců}

Značka je primárně spojována s názvem firmy, s produktem, s konkrétním logotypem. Autoři Kotler a Keller (2009) uvádějí ve své publikaci definici značky Americké marketingové asociace. Ta ř́ká, že značka může mít podobu jména, výrazu, znaku, symbolu nebo to může 
být design či jejich kombinace. Kunerth a Mosley (2011) ve svém díle propojili pojmy značka a personální marketing. Uvádějí, že je cílem značky přilákat nové zaměstnance a udržet si zaměstnance stávající. V momentě, kdy začala být značka aplikována do řízení lidských zdrojů, vznikl nový koncept tzv. "employer branding". Také Backhaus a Tikoo (2004) uvádějí, že prostřednictvím propojení filozofie značky a filozofie řízení lidských zdrojů došlo ke vzniku nové filozofie - filozofie budování „značky zaměstnavatele“. Budování značky zaměstnavatele dle autorů Backhaus a Tikoo (2004) a Love a Singh (2011) diferencuje podnik jako zaměstnavatele a je jeho konkurenční výhodou.

Termín „značka zaměstnavatele - tzv. employer branding“ byl poprvé prezentován roku 1996 pány Timem Amblerem a Simonem Barrowem (1996) na půdě London Business School jako balíček funkčních, ekonomických a psychologických výhod, které jsou poskytovány zaměstnavatelem a slouží k jeho identifikaci.

Tak jako produktová značka nabízí výhody svým spotřebitelům, tak také značka zaměstnavatele nabízí výhody zaměstnancům (Ambler and Barrow, 1996). Podobný pohled na employer branding má i Edwards (2010), který uvádí, že značku zaměstnavatele lze označit jako aktivitu uplatňující principy marketingu v oblasti řízení lidských zdrojů (HR).

Autoři Backhaus a Tikoo (2004), Mosley (2007) a Love a Singh (2011) se domnívají, že je značka zaměstnavatele koncipována zcela $\mathrm{v}$ souladu s produktem společnosti a v souladu s firemní značkou. Jejím primárním úkolem je působit na potenciální zaměstnance, vytvářet a budovat pověst firmy jako úspěšného zaměstnavatele směrem ven, ale budování vztahu se stávajícími zaměstnanci je opomíjeno.

Mosley (2007) ve svém př́ispěvku uvádí, že se v současné době v souvislosti s budováním značky zaměstnavatele uplatňuje tzv. integrovaný přístup. Aktivity zaměřené na získávání nových zaměstnanců jsou ovlivněny získanými zkušenostmi od stávajících zaměstnanců a budování značky zaměstnavatele je v souladu s firemní značkou a kulturou.

Úspěch při budování značky zaměstnavatele spočívá ve spolupráci mezi odděleními marketingu a odděleními zabývajícími se lidskými zdroji (Ritson, 2002). Tento poznatek rozšíril Minchington (2008), který podmínil úspěch budování značky zaměstnavatele nejen spoluprací mezi odděleními marketingu a lidských zdrojů, ale také poukázal na nutnost efektivní komunikace, a to jak uvnitř firmy, tak i ve vnějším prostředí.

Budování značky zaměstnavatele může podniku pomoci při dosahování jeho cílů. Obecně platí, že hlavní úlohou značky je poskytnout přidanou hodnotu, např́íklad v podobě spokojených zaměstnanců, nižších nákladů spojených s fluktuací či v oblasti náboru nových, kvalitních zaměstnanců (Barrow a Mosley, 2005).

Dle Baxe (2011) souvisí otázka značky zaměstnavatele s autentickým a přesvědčivým předáváním firemních hodnot a zkušeností potenciálním a stávajícím zaměstnancům. Jinými slovy, strategie značky zaměstnavatele je zaměřena na snahu přesvědčit současné i potenciální zaměstnance o tom, že právě hodnoty firemní kultury, uplatňované zaměstnavatelem, jsou určeny pro zajímavé a perspektivní zaměstnance ( $\mathrm{z}$ pohledu práce pro takovouto firmu) a slouží tak k jejich stabilizaci. 


\section{Metodika výzkumu využívání nástrojů (interního) HR marketingu}

K posouzení významu a způsobu využívání interního personálního marketingu s důrazem na oblast budování kvalitní značky zaměstnavatele z pohledu stávajících zaměstnancủ byl proveden výzkum mezi významnými zaměstnavateli Libereckého kraje. $\mathrm{K}$ naplnění cíle primárního výzkumu byl zvolen nejprve kvalitativní výzkum, provedený s vybranými HR manažery největších zaměstnavatelů Libereckého kraje. V návaznosti na zjištění z tohoto kvalitativního výzkumu byl vytvořen dotazník pro kvantitativní výzkum s cílem získat měřitelná číselná data. Pro svou adresnost a také pro svou finanční a časovou nenáročnost i následnou jednodušší možnost zpracování byla použita výzkumná metoda sběru dat formou online elektronického dotazování, tzv. CAWI - Computer Assisted Web Interviewing, tzn. dotazování na webovém formuláři (Kozel a kol., 2011). Informace od respondentů byly získávány prostřednictvím linku $\mathrm{v}$ e-mailu, který odkazoval na dotazník, umístěný na stránkách SurveyMonkey. Před samotným odesláním e-mailu (s odkazem na dotazník) byli všichni respondenti telefonicky kontaktováni a požádáni o vyplnění dotazníku.

Jako nástroj sběru primárních dat byl použit strukturovaný dotazník, který obsahoval 19 otázek a byl rozčleněn do 5 částí. Obsah a struktura otázek vycházely z rešerše zdrojů v oblasti personálního marketingu i analýzy potřeb pro stávající výzkum. V první části vyplňovali respondenti identifikační údaje. Ve druhé části odpovídali na otázky, týkající se využívání personálního marketingu v podnikové praxi. Třetí, samostatná část dotazníku, se zaměřila na nábor jako významnou oblast personálního marketingu. Čtvrtá část se věnovala oblasti spokojenosti zaměstnanců, pověsti zaměstnavatele a podpoře personálního marketingu vedením firmy. Závěrečná část dotazníku sledovala informace ve vazbě na využívání sociálních médií jako významného prostředku HR marketingu. Jako motivační faktor, zvyšující návratnost dotazníků, byla respondentům nabídnuta možnost získání výsledků dotazování. Koncepci primárního výzkumu přestavuje Obrázek 1.

Obrázek 1: Koncepce kvantitativního výzkumu využívání nástrojů HR marketingu

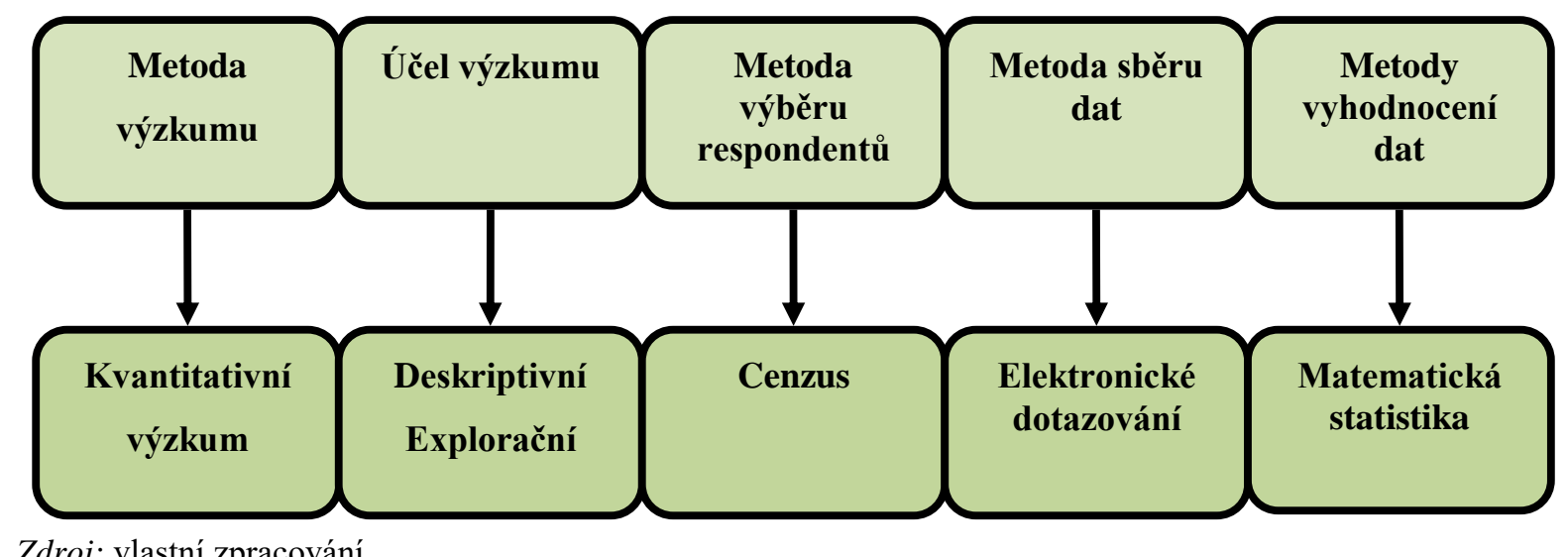

Cílem celého výzkumu bylo zhodnotit oblast personálního marketingu ve vybraných společnostech, které jsou největšími zaměstnavateli Libereckého kraje. Vzhledem k omezenému rozsahu tohoto prríspěvku se prezentované výsledky zaměřují pouze na dílčí část, a to na využívání interního personálního marketingu u těchto firem. Základní soubor tvořili všichni největší zaměstnavatelé Libereckého kraje. Podkladem pro určení základního souboru byly strategické dokumenty Statutárního města Liberec ("Strategická analýza pro rozvojovou oblast Ekonomika, podnikatelské prostředí a trh práce”), kde byli uvedeni největší zaměstnavatelé Libereckého kraje a dokumenty Úřadu práce ("Největší zaměstnavatelé Libereckého kraje"). Celkem bylo v těchto dokumentech vymezeno a tím pádem také 
osloveno všech 84 firem (HR manažerů), což byli všichni respondenti uvedení ve výše zmiňovaných dokumentech. Oslovováni byli vrcholoví pracovníci z oblasti lidských zdrojů (HR manažeři) z těchto firem. K vyhodnocení bylo získáno 58 vyplněných dotazníků, návratnost $\mathrm{z}$ oslovených respondentů tedy činila $69 \%$. Podrobné výsledky a zjištění využívání personálního marketingu (prostřednictvím důležitosti nástrojů stabilizace zaměstnanců, majících vliv na značku zaměstnavatele) u největších zaměstnavatelů v Libereckém kraji jsou prezentovány $\mathrm{v}$ další části příspěvku. Vzhledem k relativně malému počtu respondentů byly všechny dotazníky kontrolovány z hlediska úplnosti a prošly také logickou kontrolou, která se zaměřila na kvalitu provedeného výzkumu i samotných dat (Kozel a kol., 2011).

\section{Zpracování primárních dat}

Primární data od největších zaměstnavatelů Libereckého kraje byla sbírána v květnu a červnu roku 2015. Následně byla kódována a zpracována statistickým softwarem ("R").

V rámci statického vyhodnocení byly použity nominální, ordinální a kardinální proměnné.

U nominálních proměnných bylo určeno, zda je v zastoupení dvojic jednotlivých kategorií proměnných na dané hladině statistické významnosti $\alpha$ statisticky významný rozdíl, a to pomocí Pearsonova $\lambda^{2}$ testu.

Testovaná hypotéza

Alternativní hypotéza

Testovací kritérium:

$$
\begin{aligned}
& \mathrm{H}_{0}: \mathrm{p} 1=\mathrm{p} 2 \quad \text { (četnost výskytu jevu 1= četnost výskytu jevu 2) } \\
& \mathrm{H}_{\mathrm{A}}: \mathrm{p} 1 \neq \mathrm{p} 2
\end{aligned}
$$

$$
\frac{\left(n_{1}-n_{2}\right)^{2}}{n_{1}+n_{2}} \geq \mathrm{X}_{\alpha, 1}^{2}
$$

Pokud bylo testovací kritérium $\geq \lambda_{\alpha}^{2}$, , pak byla zamítnuta hypotéza $\mathrm{H}_{0}$ o shodě četností jevů na hladině významnosti $\alpha$. Následně byla spočítána p-hodnota, určující, jaké chyby se lze dopustit při zamítnutí hypotézy $\mathrm{H}_{0}$. $n_{1}, n_{2}$ : počty zastoupení jednotlivých jevi

Omezeni: platí pro $n_{1}+n_{2}>30$

Při analýze kardinálních proměnných byla nejprve provedena deskriptivní statistika $\mathrm{s}$ výpočtem základních parametrů polohy a rozptýlení. Dále bylo provedeno ověření předpokladů o homogenitě a normalitě. Pokud byly splněny základní předpoklady, byly zkoumány vazby mezi jednotlivými soubory. Předmětem zjištění byla identifikace nástrojů, které jsou důležité pro stabilizaci stávajících zaměstnanců v návaznosti na velikost podniku. Jednalo se o zamítnutí či nezamítnutí nulové hypotézy $\mathrm{H}_{0}$ pomocí sady $\mathrm{t}$-testů.

V případě zamítnutí normality Shapiro-testem při jejím významném narušení byl použit neparametrický Wilcoxonův test. V celém hodnocení dat se pracuje s hladinou významnosti $\alpha=0,05$.

\section{Výsledky dotazníkového šetření}

V rámci kvantitativního výzkumu bylo celkem osloveno 84 firem (odborníků na lidské zdroje $\mathrm{z}$ podniků, které jsou největšími zaměstnavateli $\mathrm{v}$ Libereckém kraji). $\mathrm{K}$ vyhodnocení bylo předáno 58 zapsaných dotazníků. Průzkumu se zúčastnilo 19 zástupců společností o velikosti 
50-249 zaměstnanců $(32,8 \%)$ a 39 zástupců podniků o velikosti nad 250 zaměstnanců $(67,2 \%)$.

Předmětem zkoumání a následného vyhodnocení primárních dat $\mathrm{v}$ rámci tohoto příspěvku byla pouze část dat získaných z výzkumu, a to konkrétně identifikace a důležitost nástrojů, které využívají odborníci na lidské zdroje pro stabilizaci stávajících zaměstnanců v rámci využívání personálního marketingu.

Odborníci na lidské zdroje z firem, které jsou největšími zaměstnavateli Libereckého kraje, hodnotili pomocí škály $1-6$ výčet nabízených nástrojů stabilizace stávajících zaměstnanců, kde hodnocení 1 = maximálně důležité a 6 = zcela nedůležité (tabulka 1). Odborníci měli možnost rozšśřit předložené nástroje o další. Předmětem zkoumání bylo vyhodnocení dat v závislosti na velikost podniku.

Jako důležitý je vnímán nástroj, jehož medián leží v intervalu $<1 ; 2>$, neutrální důležitost má nástroj, jehož medián leží v intervalu $<3 ; 4>$ a nedůležitý je pak nástroj, jehož medián leží $\mathrm{v}$ intervalu $\langle 5 ; 6\rangle$.

Tabulka 1: Nástroje stabilizace zaměstnanců a jejich důležitost

\begin{tabular}{|c|c|c|c|c|}
\hline \multicolumn{5}{|c|}{ Důležitost nástrojů pro stabilizaci zaměstnanců } \\
\hline \multirow[t]{2}{*}{ Nástroj } & \multicolumn{2}{|c|}{$\begin{array}{c}\text { stř̌ední podniky } \\
(\mathbf{5 0 - 2 4 9} \\
\text { zaměstnanců) }\end{array}$} & \multicolumn{2}{|c|}{$\begin{array}{c}\text { velké podniky } \\
\text { (nad 250 } \\
\text { zaměstnanců) }\end{array}$} \\
\hline & Medián & Důležitost & Medián & Důležitost \\
\hline 1. Výše platu & 1 & důležitý & 1 & důležitý \\
\hline 2. Vztahy s nadř́zeným & 2 & důležitý & 1 & důležitý \\
\hline 3. Jistota pracovní pozice & 1 & důležitý & 1 & důležitý \\
\hline 4. Seberealizace & 2 & důležitý & 2 & důležitý \\
\hline 5. Společenská prestiž pracovní pozice & 3 & neutrální & 3 & neutrální \\
\hline 6. Dobré jméno firmy & 2 & důležitý & 2 & důležitý \\
\hline 7. Možnost uplatnit vlastní iniciativu & 3 & neutrální & 2 & důležitý \\
\hline 8. Efektivnost vedení organizace & 2 & důležitý & 2 & důležitý \\
\hline 9. Pracovní doba & 2 & důležitý & 2 & důležitý \\
\hline 10. Zaměstnanecké výhody & 1 & důležitý & 2 & důležitý \\
\hline 11. Náplň práce & 2 & důležitý & 2 & důležitý \\
\hline 12. Množství práce & 2 & důležitý & 2 & důležitý \\
\hline 13. Rozmanitost práce & 3 & neutrální & 3 & neutrální \\
\hline 14. Zvyšování kvalifikace & 3 & neutrální & 2 & důležitý \\
\hline 15. Přátelské vztahy mezi kolegy & 2 & důležitý & 2 & důležitý \\
\hline 16. Pracovní prostředí & 3 & neutrální & 2 & důležitý \\
\hline 17. Kariérový růst & 3 & neutrální & 2 & důležitý \\
\hline 18. Sdílení pracovního místa & 4 & neutrální & 4 & neutrální \\
\hline
\end{tabular}

Zdroj: vlastní zpracování

Na základě tabulky 1 lze konstatovat, že většinu předložených nástrojů vnímají odborníci na lidské zdroje jako důležité prostředky stabilizace zaměstnanců. Pouze nástroje „společenská prestiž pracovní pozice“, „rozmanitost práce“, a „sdílení pracovního místa“ jsou hodnoceny respondenty (jak z podniků s 50-249 zaměstnanci, tak z podniků s 250 a více zaměstnanci) shodně jako „neutrální“. Těmto výše vyjmenovaným nástrojům není 
respondenty prrikládán takový význam v rámci stabilizace zaměstnanců jako nástrojům ostatním.

Rozdíl v hodnocení nástrojů mezi skupinami respondentů (z podniků s 50-249 zaměstnanci a z podniků s 250 a více zaměstnanci) lze spatřit u nástrojů „možnost uplatnit vlastní iniciativu“, „zvyšování kvalifikace“, „pracovní prostředí“ a „kariérový růst“. Respondenti z velkých podniků považují tyto nástroje za důležitější než respondenti ze středních podniků. Lze tedy konstatovat, že je u nástrojů 7, 14, 16 a 17 indikován rozdíl v hodnocení jejich důležitosti.

V následující tabulce 2 jsou zpracovávány odpovědi jako kardinální proměnné. Pro zpracování bylo použito následující kódování: B11.1 = výše platu, B11.2 = vztahy s nadřízeným, B11.3 = jistota pracovní pozice, B11.4 = seberealizace, B11.5 = společenská prestiž pracovní pozice, B11.6 = dobré jméno firmy, B11.7 = možnost uplatnit vlastní iniciativu, B11.8 = efektivnost vedení organizace, B11.9 = pracovní doba, B11.10= zaměstnanecké výhody, $\mathrm{B} 11.11$ = náplň práce, $\mathrm{B} 11.12=$ množství práce, $\mathrm{B} 11.13=$ rozmanitost práce, B11.14 = zvyšování kvalifikace, B11.15 = přátelské vztahy mezi kolegy, B11.16 = pracovní prostředí, B11.17 = kariérový růst a B11.18 = sdílení pracovního místa. Tabulka obsahuje výpočty aritmetického průměru, směrodatné odchylky, konfidenční interval, medián a p-hodnoty pro závěry Wilcoxonova neparametrického testu shody středních hodnot pro jednotlivé hodnocené nástroje a velikosti společností.

Aritmetický průměr je statistická veličina, vyjadřující stř̌ední hodnotu z testovaného souboru. Směrodatná odchylka určuje, jak moc jsou hodnoty rozptýleny či odchýleny od průměru hodnot. Konfidenční interval je interval, kde se nachází stř̌ední hodnota statistického souboru se spolehlivostí 1- $\alpha$. Medián dělí soubor hodnot na dvě stejně velké části. 
Tabulka 2: Statistické vyhodnocení důležitosti nástrojů stabilizace zaměstnanců

\begin{tabular}{|c|c|c|c|c|c|c|c|}
\hline Nástroj & $\begin{array}{l}\text { Velikost } \\
\text { společnosti }\end{array}$ & $\overline{\boldsymbol{x}}$ & sd & $\bar{x}-t \frac{s}{\sqrt{n}}$ & $\bar{x}+t \frac{s}{\sqrt{n}}$ & Medián & $\begin{array}{l}\text { p-hodnota } \\
\text { Wilcoxonova } \\
\text { testu středních } \\
\text { hodnot }\end{array}$ \\
\hline \multirow[t]{2}{*}{ B11.1 } & střední & 1,7 & 1,32 & 0,7 & 2,7 & 1 & 0,677 \\
\hline & velký & 1,6 & 0,93 & 1,3 & 2,0 & 1 & \\
\hline \multirow[t]{2}{*}{ B11.2 } & střední & 2,0 & 1,32 & 1,0 & 3,0 & 2 & 0,351 \\
\hline & velký & 1,5 & 0,63 & 1,3 & 1,7 & 1 & \\
\hline \multirow[t]{2}{*}{ B11.3 } & střední & 1,8 & 1,39 & 0,7 & 2,8 & 1 & 1,000 \\
\hline & velký & 1,6 & 0,89 & 1,3 & 1,9 & 1 & \\
\hline \multirow[t]{2}{*}{ B11.4 } & střední & 2,8 & 1,48 & 1,7 & 3,9 & 2 & 0,116 \\
\hline & velký & 1,9 & 0,84 & 1,6 & 2,3 & 2 & \\
\hline \multirow[t]{2}{*}{ B11.5 } & střední & 3,4 & 1,24 & 2,5 & 4,4 & 3 & 0,177 \\
\hline & velký & 2,7 & 1,05 & 2,3 & 3,1 & 3 & \\
\hline \multirow[t]{2}{*}{ B11.6 } & střední & 2,8 & 1,92 & 1,3 & 4,2 & 2 & 0,335 \\
\hline & velký & 1,9 & 0,91 & 1,6 & 2,3 & 2 & \\
\hline \multirow[t]{2}{*}{ B11.7 } & střední & 3,4 & 1,33 & 2,4 & 4,4 & 3 & 0,009 \\
\hline & velký & 2,2 & 0,94 & 1,9 & 2,6 & 2 & \\
\hline \multirow[t]{2}{*}{ B11.8 } & střední & 2,4 & 1,33 & 1,4 & 3,4 & 2 & 0,694 \\
\hline & velký & 2,2 & 1,11 & 1,8 & 2,6 & 2 & \\
\hline \multirow[t]{2}{*}{ B11.9 } & střední & 2,3 & 1,58 & 1,1 & 3,5 & 2 & 0,790 \\
\hline & velký & 2,2 & 0,89 & 1,9 & 2,5 & 2 & \\
\hline \multirow[t]{2}{*}{ B11.10 } & střední & 1,8 & 1,09 & 1,0 & 2,6 & 1 & 0,203 \\
\hline & velký & 2,1 & 0,88 & 1,8 & 2,4 & 2 & \\
\hline \multirow[t]{2}{*}{ B11.11 } & střední & 2,2 & 1,20 & 1,3 & 3,1 & 2 & 0,821 \\
\hline & velký & 2,1 & 0,94 & 1,7 & 2,4 & 2 & \\
\hline \multirow[t]{2}{*}{ B11.12 } & střední & 2,4 & 1,13 & 1,6 & 3,3 & 2 & 0,713 \\
\hline & velký & 2,3 & 0,87 & 1,9 & 2,6 & 2 & \\
\hline \multirow[t]{2}{*}{ B11.13 } & střední & 2,9 & 0,78 & 2,3 & 3,5 & 3 & 0,148 \\
\hline & velký & 2,4 & 1,10 & 2,0 & 2,8 & 3 & \\
\hline \multirow[t]{2}{*}{ B11.14 } & střední & 3,3 & 1,41 & 2,3 & 4,4 & 3 & 0,081 \\
\hline & velký & 2,4 & 0,93 & 2,1 & 2,7 & 2 & \\
\hline \multirow[t]{2}{*}{ B11.15 } & střední & 2,4 & 1,13 & 1,6 & 3,3 & 2 & 0,144 \\
\hline & velký & 1,9 & 0,97 & 1,5 & 2,2 & 2 & \\
\hline \multirow[t]{2}{*}{ B11.16 } & střední & 2,7 & 1,32 & 1,7 & 3,7 & 3 & 0,056 \\
\hline & velký & 1,8 & 0,71 & 1,5 & 2,1 & 2 & \\
\hline \multirow[t]{2}{*}{ B11.17 } & střední & 3,0 & 1,58 & 1,8 & 4,2 & 3 & 0,356 \\
\hline & velký & 2,4 & 1,03 & 2,0 & 2,8 & 2 & \\
\hline \multirow[t]{2}{*}{ B11.18 } & střední & 4,2 & 1,20 & 3,3 & 5,1 & 4 & 0,465 \\
\hline & velký & 3,9 & 1,36 & 3,3 & 4,4 & 4 & \\
\hline
\end{tabular}

Zdroj: vlastní zpracování

Statistické veličiny, uvedené v tabulce 2 , potvrzují výsledky analýzy předcházející (tabulka 1). Nejdůležitějším nástrojem, ovlivňujícím stabilizaci stávajících zaměstnanců, se z pohledu odborníků na lidské zdroje (u velkých i středních podniků) jeví „výše platu“ a ,jistota pracovní pozice“. Naopak jako nejméně důležitý nástroj pro stabilizaci zaměstnanců se u těchto odborníků jeví nástroj „sdílení pracovního místa“. 
Analýza středních hodnot pomocí neparametrického Wilcoxonova testu prokázala, že je statisticky významný rozdíl v hodnocení důležitosti nástroje 7 . To potvrzuje závěry analýzy mediánů a rozložení. Ostatní rozdíly, které předchozí analýza naznačila, nebyly analýzou středních hodnot prokázány.

Dále byla provedena analýza vlivu velikosti podniku na skladbu odpovědí metodikou jednofaktorové analýzy rozptylu ANOVA. Souhrnné výsledky prezentuje následující tabulka 3.

$\mathrm{H}_{0}$ : na hodnocení nemá velikost podniku vliv (efekty $\alpha$ jsou nulové)

$\mathrm{H}_{\mathrm{A}}$ : na hodnocení má velikost podniku vliv

Pokud je $H V \leq 0,05$, pak lze konstatovat, že odpovědi na otázku v závislosti na velikosti podniku jsou statisticky významně odlišné.

Tabulka 3: Vyhodnocení vlivu velikosti podniku - ANOVA

\begin{tabular}{|l|c|c|c|}
\cline { 3 - 4 } \multicolumn{2}{c}{} & \multicolumn{2}{c|}{ Velikost podniku } \\
\hline 1. Výše platu & Označení & Statistika F & HV \\
\hline 2. Vztahy s nadřízeným & B11.1 & 0,007 & 0,932 \\
\hline 3. Jistota pracovní pozice & B11.2 & 2,511 & 0,122 \\
\hline 4. Seberealizace & B11.3 & 0,209 & 0,650 \\
\hline 5. Společenská prestiž pracovní pozice & B11.4 & 4,738 & 0,036 \\
\hline 6. Dobré jméno firmy & B11.5 & 3,030 & 0,091 \\
\hline 7. Možnost uplatnit vlastní iniciativu & B11.6 & 3,419 & 0,072 \\
\hline 8. Efektivnost vedení organizace & B11.7 & 9,491 & 0,004 \\
\hline 9. Pracovní doba & B11.8 & 0,285 & 0,597 \\
\hline 10. Zaméstnanecké výhody & B11.9 & 0,106 & 0,746 \\
\hline 11. Náplň práce & B11.10 & 0,825 & 0,370 \\
\hline 12. Množství práce & B11.11 & 0,166 & 0,686 \\
\hline 13. Rozmanitost práce & B11.12 & 0,252 & 0,618 \\
\hline 14. Zvyšování kvalifikace & B11.13 & 1,753 & 0,194 \\
\hline 15. Přátelské vztahy mezi kolegy & B11.14 & 5,416 & 0,026 \\
\hline 16. Pracovní prostř́edí & B11.15 & 2,269 & 0,140 \\
\hline 17. Kariérový růst & B11.16 & 6,681 & 0,014 \\
\hline 18. Sdílení pracovního místa & B11.17 & 2,016 & 0,164 \\
\hline
\end{tabular}

Zdroj: vlastní zpracování

Z tabulky 3 vyplývá, že analýza rozptylu naznačuje rozdíly u hodnocení nástrojů 4,7,14 a 16 . Závěr je shodný se závěry analýzy rozdílů mediánů a rozdělení četností.

\subsection{Diskuse výsledků výzkumu}

Následující tabulka 4 shrnuje výsledky předchozích analýz, které se zabývaly odpověd'mi respondentů s ohledem na velikost podniků. Je patrné, že rozdíl $\mathrm{v}$ hodnocení nástroje „možnost uplatnit vlastní iniciativu“ odborníky na lidské zdroje z velkých a středních podniků (největší zaměstnavatelé Libereckého kraje) je možno považovat za prokázaný (potvrdily ho všechny tr̆i způsoby testování). Naproti tomu rozdíly v hodnocení nástrojů „,seberealizace“, „Zvyšování kvalifikace“, „,pracovní prostředí“ a „kariérový růst“" byly prokázány pouze jednou nebo dvěma metodami ze tř́. Je tedy na místě přijmout konzervativní závěr, že rozdíly se zde 
vyskytují, ale jejich statistickou významnost/nevýznamnost nelze dostatečně prokázat nebo vyvrátit.

Tabulka 4: Souhrnné hodnocení nástrojů odborníky na lidské zdroje (rozdíly v hodnocení)

\begin{tabular}{|c|c|c|c|}
\hline Nástroj & $\begin{array}{l}\text { Analýza rozdílu } \\
\text { mediánů }\end{array}$ & $\begin{array}{c}\text { Analýza } \\
\text { stř́edních } \\
\text { hodnot } \\
\text { Wilcoxonovým } \\
\text { testem }\end{array}$ & ANOVA \\
\hline 1. Výše platu & rozdíl neprokázán & rozdíl neprokázán & rozdíl neprokázán \\
\hline 2. Vztahy s nadř́zeným & rozdíl neprokázán & rozdíl neprokázán & rozdíl neprokázán \\
\hline 3. Jistota pracovní pozice & rozdíl neprokázán & rozdíl neprokázán & rozdíl neprokázán \\
\hline 4. Seberealizace & rozdíl neprokázán & rozdíl neprokázán & rozdíl prokázán \\
\hline $\begin{array}{l}\text { 5. Společenská prestiž } \\
\text { pracovní pozice }\end{array}$ & rozdíl neprokázán & rozdíl neprokázán & rozdíl neprokázán \\
\hline 6. Dobré jméno firmy & rozdíl neprokázán & rozdíl neprokázán & rozdíl neprokázán \\
\hline $\begin{array}{l}\text { 7. Možnost uplatnit vlastní } \\
\text { iniciativu }\end{array}$ & rozdíl prokázán & rozdíl prokázán & rozdíl prokázán \\
\hline $\begin{array}{l}\text { 8. Efektivnost vedení } \\
\text { organizace }\end{array}$ & rozdíl neprokázán & rozdíl neprokázán & rozdíl neprokázán \\
\hline 9. Pracovní doba & rozdíl neprokázán & rozdíl neprokázán & rozdíl neprokázán \\
\hline 10. Zaměstnanecké výhody & rozdíl neprokázán & rozdíl neprokázán & rozdíl neprokázán \\
\hline 11. Náplň práce & rozdíl neprokázán & rozdíl neprokázán & rozdíl neprokázán \\
\hline 12. Množství práce & rozdíl neprokázán & rozdíl neprokázán & rozdíl neprokázán \\
\hline 13. Rozmanitost práce & rozdíl neprokázán & rozdíl neprokázán & rozdíl neprokázán \\
\hline 14. Zvyšování kvalifikace & rozdíl prokázán & rozdíl neprokázán & rozdíl prokázán \\
\hline $\begin{array}{l}\text { 15. Přátelské vztahy mezi } \\
\text { kolegy }\end{array}$ & rozdíl neprokázán & rozdíl neprokázán & rozdíl neprokázán \\
\hline 16. Pracovní prostředí & rozdíl prokázán & rozdíl neprokázán & rozdíl prokázán \\
\hline 17. Kariérový růst & rozdíl prokázán & rozdíl neprokázán & rozdíl neprokázán \\
\hline 18. Sdílení pracovního místa & rozdíl neprokázán & rozdíl neprokázán & rozdíl neprokázán \\
\hline
\end{tabular}

Primární data, získaná od velkých a středních podniků v Libereckém kraji (od největších zaměstnavatelů tohoto kraje) pak ukazují na to, že nástroje „,výše platu“, „vztahy s nadřízeným“, ,jistota pracovní pozice“, „seberealizace“, „dobré jméno firmy“, „efektivní vedení organizace“, „pracovní doba“, „zaměstnanecké výhody“, „náplň práce“, množství práce“ a „přátelské vztahy mezi kolegy“ jsou vnímány odborníky na lidské zdroje (bez rozdílu ve velikosti podniku) jako velmi důležité. Naopak nástroje „společenská prestiž pracovní pozice“, „rozmanitost práce“, a „sdílení pracovního místa“ jsou vnímány odborníky na lidské zdroje (bez rozdílu ve velikosti podniku) jako méně důležité. U nástroje „možnost uplatnit vlastní iniciativu“ byl prokázán rozdíl v odpovědích v závislosti na velikosti podniku všemi třemi analýzami. Lze tedy konstatovat, že většina nástrojů, zkoumaná v primárním výzkumu, ukazuje na jejich význam $\mathrm{v}$ oblasti interního personálního marketingu u největších zaměstnavatelů $\mathrm{v}$ Libereckém kraji a poukazuje tak na oblasti, na které by se měl zaměstnavatel zaměřit při budování své kvalitní značky a udržení si kvalitních zaměstnanců.

Jak ukázaly výsledky, nejdůležitějším nástrojem, ovlivňujícím stabilizaci stávajících zaměstnanců, se $\mathrm{z}$ pohledu odborníků na lidské zdroje u největších zaměstnavatelů 
v Libereckém kraji jeví výše platu. Tuto skutečnost potvrzují např. také Irshad a Afridi (2012), kteří uvádějí, že právě odměňování hraje klíčovou roli v motivaci zaměstnanců a tím i v jejich stabilizaci z pohledu zaměstnavatele. Podobně také Manhertz (2011) potvrzuje ve své studii, provedené mezi 738 HR manažery předních světových společností, že klíčovými nástroji stabilizace kvalitních talentovaných zaměstnanců jsou poskytování odpovídajícího odměňování a systému benefitů. Ve srovnání s mezinárodními výsledky poukazují výsledky za Liberecký kraj (z pohledu HR manažerů) také na významnou roli jistoty pracovní pozice pro stabilizaci zaměstnanců.

Manhertz (2011) dále vyzdvihuje nutnost implementace takových oblastí do podnikové strategie, jako jsou: vytvoření podmínek pro vzdělávání a rozvoj či důraz na zainteresovanost (engagement) zaměstnanců. Tato zjištění korespondují s výsledky empirického šetření, prezentovanými v tomto př́spěvku, kde zvyšování kvalifikace či možnost seberealizace uvádějí respondenti také jako důležité, a to především ve velkých společnostech.

Statisticky testované výsledky výzkumu potvrzují význam většiny zvolených nástrojů v oblasti personálního marketingu jako důležitých faktorů pro stabilizaci kvalitních zaměstnanců u největších zaměstnavatelů v Libereckém kraji.

\section{Závěr}

Tématem př́spěvku je personální marketing, především interní personální marketing, který je důležitý prostředkem pro udržení si kvalitních zaměstnanců ve společnostech a je významný pro budování značky zaměstnavatele. Příspěvek seznamuje s aktuální oblastí personálního marketingu ve vazbě na značku zaměstnavatele a otázku stabilizace zaměstnanců, a to $\mathrm{s}$ využitím dat získaných od největších zaměstnavatelů v Libereckém kraji v roce 2015 (konkrétně HR manažerů a specialistů).

Cílem př́íspěvku bylo zhodnotit míru využívání a důležitost konkrétních nástrojů stabilizace zaměstnanců ve vazbě na oblast interního personálního marketingu a budování značky zaměstnavatele na konkrétních datech. Následně pak zjištění využít k doporučení firmám v oblasti stabilizace zaměstnancủ a využívání personálního marketingu.

Rešerše uvedená v úvodní části př́spěvku potvrzuje, že je personální marketing poměrně novým, nicméně velmi významným oborem, důležitým pro získávání a udržení si kvalitních zaměstnanců. Současně analýza sekundárních zdrojů potvrdila skutečnost, že převládá nedostatek odborné vědecké literatury a výsledků výzkumů na téma personální marketing.

Zjištění, vyplývající z teoretické i empirické části, poukazují na význam nástrojů, jako jsou především výše platu, vztahy s nadřízeným, jistota pracovní pozice či seberealizace v oblasti interního personálního marketingu a jejich důležitost pro udržení si spokojených a motivovaných zaměstnanců. Zároveň prŕíspěvek upozorňuje i na to, že zaměstnavatelé by si měli uvědomovat význam těchto nástrojů, pečovat o kvalitní značku zaměstnavatele a snažit se identifikovat právě ty faktory, které mají na udržení si zaměstnanců největší vliv. Při identifikaci těchto faktorů by také měli pracovat i s názory samotných zaměstnanců, a to i s ohledem na specifika různých firemních kultur či generací (např. generace Y nebo Z). Tyto faktory je nutné nejen identifikovat (např̀. z pohledu zaměstnanců v rámci průzkumů spokojenosti), ale cíleně je implementovat do personální i celopodnikové strategie.

Výzkumný tým si uvědomuje, že pro zobecnění závěrů je potřeba provést rozsáhlejší výzkum, který by zohlednil všechny velikosti podniků a další aspekty, například obor podnikání 
či právě posouzení z pohledu zaměstnanců společností. Vzhledem k tomu, že se jedná o aktuální a rozvíjející se oblast, na které závisí úspěšnost zaměstnavatele, si výzkumný tým klade za cíl ve zkoumání této problematiky pokračovat a prohloubit práci se sekundárními i primárními daty.

\section{Poděkování}

Tento článek vznikl za podpory grantu SGS „Využití personálního marketingu v podnikové praxi“".

\section{Literatura}

[1] AMBLER, T. a S. BARROW, 1993. The employer brand. Journal of brand management, 4(3), 185-206. ISSN 1350-231X.

[2] BACKHAUS, K. a S. TIKOO, 2004. Conceptualizing and researching employer branding. Career Development International, 9(5), 501-517. ISSN 1362-0436.

[3] BARROW, S. a R. MOSLEY, 2005. The Employer Brand: Bringing the Best of Brand Management to People at Work. West Sussex: John Wiley \& Sons. ISBN 978-0-47001273-4.

[4] BAX, J. H., 2011. Build your employer brand: A strategic approach to recruitment and retention [online]. [vid. 16. října 2015]. Dostupné z: www.randstad.ca/downloads/072711_build_your_employer_brand-staffing.pdf

[5] DEW-BECKER, I. a R. J. GORDON, 2012. The role of labor market changes in the slowdown of European productivity growth. Review of Economics and Institutions, 3(2), 1-45. ISSN 2038-1379.

[6] DVOŘÁKOVÁ, Z. et al., 2004. Slovník pojmů k ř́zení lidských zdrojů. Praha: C. H. Beck. ISBN 80-7179-468-6.

[7] EDWARDS, M. R., 2009. An integrative review of employer branding and OB theory. Personnel Review, 39(1), 5-23. ISSN 0048-3486.

[8] FARZAD, A. et al., 2008. The effect of internal marketing on organizational commitment in Iranian banks. American Journal of Applied Sciences, 5(11), 1480-1486. ISSN 1546-9239.

[9] GADDAM, S., 2008. Modeling employer branding communication: The softer aspect of HR marketing management. ICFAI Journal of Soft Skills, 2(1), 45-55. ISSN 0973-8479.

[10] IRSHAD, M. a F. AFRIDI, 2012. Factors affecting employee retention: evidence from literature review. Abasyn Journal of Social Sciences [online]. 4(1), 84-88 [vid. 4. dubna 2016]. Dostupné z: 64.17.184.140/wp-content/uploads/2012/12/V4I1-7.pdf

[11] KOTLER, P. a K. L. KELLER, 2007. Marketing Management. 12. vyd. Praha: Grada Publishing, a.s. ISBN 978-80-247-1359-5.

[12] KOZEL, R. et al., 2011. Moderní metody a techniky marketingového výzkumu. Praha: Grada Publishing. ISBN 978-80-247-3527-6.

[13] KUNERTH, B. a R. MOSLEY, 2011. Applying employer brand management to employee engagement. Strategic HR Review, 10(3), 19-26. ISSN 1475-4398.

[14] LOVE, L. F. a P. SINGH, 2011. Workplace branding: leveraging human resources management practices for competitive advantage through 'best employer' surveys. Journal of Business and Psychology, 26(2), 175-181. ISSN 1573-353X. 
[15] MANHERTZ, H., 2011. Worldwide Trends in Employee Retention: How to Keep Your Best Employees in Any Market. AchieveGlobal, Inc. [online]. [vid. 4. dubna 2016]. Dostupné z: achieveglobalmec.files.wordpress.com/2015/01/worldwide-trends-inemployee-retention.pdf

[16] MEIER, W., 1991. Strategisches Personalmarketing: Analyse - Konception Instrumente. In: W. MAIER a W. FRÖHLICH, eds. Personalmanagement in der Praxis. Wiesbaden: Gabler Verlag, s. 65. ISBN 3-409-13852-8.

[17] MINCHINGTON, B., 2008. What's employer branding without communication? [online]. [vid. 20. záŕí 2015]. Dostupné z: www.iabc.com/ cwb/archive/2008/0708/Minchington.htm

[18] MOSLEY, R. W., 2007. Customer experience, organizational culture and the employer brand. Brand Management, 15(2), 123-134. ISSN 1350-231X.

[19] RITSON, M., 2002. OPINION: marketing and HR collaborate to harness employer brand power [online]. [vid. 22. záŕí 2015]. Dostupné z: www.marketingmagazine.co.uk/news/162068/OPINION-Marketing-HR-collaborateharness-employer-brand-power/?DCMP=ILC-SEARCH

[20] UNGERMAN, O., 2015. Social media as a marketing communikacion tool by family firms. Acta academia karviniensia, 15(2), 148-156. ISSN 1212-415X.

[21] WAHBA, M. a D. ELMANADILY, 2015. Employer branding impact on employee behavior and attitudes applied study on pharmatecual in Egypt. International Journal of Management and Sustainability, 4(6), 145-162. ISSN 2306-9856.

[22] WALTER, A. a S. FÖRSTER, 2015. Befragung von Studierenden der Westsächsischen Hochschule Zwickau 2014. Chemnitz: Fokus prints. ISSN 1612-1686.

[23] WIMMERS, J., 2009. HR Marketing From Job Advertising to Employer Branding. Norderstedt: GRIN Verlag. ISBN 978-3-640-44934-7. 